Vol. 3 No.2 Juni 2021

Ensiklopedia Social Review

http://jurnal.ensiklopediaku.org

\title{
KEDUDUKAN KOMISI PENGAWAS PERSAINGAN USAHA DALAM HAL TERJADINYA MERGER
}

\author{
SRI AGUSTINI \\ Sekolah Tinggi Ilmu Hukum Padang \\ sriagustini@gmail.com
}

\begin{abstract}
The birth of Act No 5 Year 1999 concerning Prohibition of Monopolistic Practises and Unfair Business deliver its own message to the government to establish regulation regarding mergers as contained in Article 29 Paragraph (3) and Article 29 Paragraph (2). Growing competition between business entities in the market resulted in the business-strategy competing to find new strategies to keep their business running well. One of them with merger. The government set up Government Regulation Number 57 Year 2010 regarding the Merger or Consolidation of Business and Acquisition Agency Shares which may Result in Monopolistic Practices and Unfair Business Competition. With the aim that the implementation of the merger has clear rules and legal certainty in the implementation of the merger. Based on this, the authors want to try to raise issues about how the Commission's position in the event of a merger and how the implementation of the merger based on Government Regulation Number 57 Year 2010. In writing this thesis, the author uses research methods to the nature of juridical normative in descriptive research, and data obtained from the research literature which is then processed by way of editing ang to analysis with analiysis of qualitative. Techniques of data collection in done by the study of documents. From the result of research conducted in can be concluded that the Commission has a very important position because it was believed by the Government Regulation Number 57 Year 2010 as an institution that became the backbone, enforcement and oversight of merger. As for the implementation of the merger is done by the company's internal preparation to meet the requirements of the merger, and after they met, then proceed with the impelementation phase of the merger according to Government Regulation Number 57 Year 2010 regarding the plan of merger must be notified to the Commission and Business can also do consulting on a voluntary basis to the Commission.
\end{abstract}

Keywords: KPPU, Merger, Position.

Abstrak: Lahirnya Undang-Undang No. 5 tahun 1999 tentang Larangan Praktik Monopoli dan Persaingan Usaha Tidak Sehat memberikan amanat tersendiri kepada pemerintah untuk membentuk peraturan pemerintah tentang merger sebagaimana terkandung dalam Pasal 29 ayat (3) dan Pasal 29 ayat (2). Dengan banyaknya persaingan antar badan usaha dalam pasar mengakibatkan pelaku usaha saling berlomba menemukan strategi-stategi baru agar usahanya tetap berjalan dengan baik. Salah satunya dengan melakukan merger. Oleh karena itu, pemerintah membentuk PP No. 57 Tahun 2010 tentang Penggabungan atau Peleburan Badan usaha dan Pengambilalihan Saham yang Dapat Mengakibatkan Terjadinya Praktik Monopoli dan Persaingan Usaha Tidak Sehat. Dengan tujuan agar pelaksanaan merger memiliki aturan yang jelas dan adanya kepastian hukum dalam pelaksanaan merger. Berdasarkan hal tersebut, penulis ingin mencoba mengangkat permasalahan mengenai

254 Lembaga Penelitian dan Penerbitan Hasil Penelitian Ensiklopedia $\quad$ E-ISSN: 2657-0300

P-ISSN: 2657-0319 
bagaimana kedudukan KPPU dalam hal terjadinya merger dan bagaimana pelaksanaan merger berdasarkan PP No 57 Tahun 2010. Dalam penulisan skripsi ini penulis menggunakan metode penelitian yuridis normatif dengan sifat penelitian deskriptif, dan datanya diperoleh dari penelitian kepustakaan yang kemudian diolah dengan cara editing serta dianilisis dengan analisisi kualitatif. Teknik pengumpulan data dilakukan dengan studi dokumen. Dari hasil penulisan dapat ditarik kesimpulan bahwa KPPU memiliki kedudukan yang sangat penting karena dipercaya oleh PP No. 57/2010 sebagai lembaga yang menjadi penopang, penegak dan pengawas terjadinya merger, sedangkan untuk pelaksanaan merger dilakukan dengan tahap persiapan internal perusahaan untuk memenuhi kebutuhan persyaratan merger, dan setelah semuanya terpenuhi, maka dilanjutkan dengan tahap pelaksanaan merger menurut PP No. 57/2010 mengenai rencana merger wajib diberitahukan kepada KPPU serta pelaku usaha juga dapat melakukan konsultasi secara sukarela kepada KPPU.

Kata Kunci: KPPU, Merger, Kedudukan.

\section{A. Pendahuluan}

Undang-Undang Nomor 5 Tahun 1999 tentang Larangan Praktik Monopoli dan Persaingan Usaha Tidak Sehat (selanjutnya disebut UU Anti Monopoli) telah diundangkan sejak 5 maret 1999 dan berlaku secara efektif satu tahun kemudian. UU Antimonopoli ini dibuat dengan tujuan untuk menciptakan iklim usaha yang sehat, efektif dan efisien, serta mendorong pertumbuhan ekonomi, menjaga agar ekonomi pasar bekerja dengan wajar, serta mencegah timbulnya pemusatan kekuatan ekonomi pada pelaku usaha tertentu yang dapat menghalangi persaingan yang sehat dan wajar (Syamsul Maarif, 2010). Dengan semakin maraknya bermunculan usaha-usaha baru di dunia persaingan usaha yang saling berkompetisi untuk menghasilkan produk yang lebih baik agar semakin diminati oleh masyarakat sebagai konsumen, membuat pelaku usaha memunculkan strategi-strategi baru dalam mengoperasikan usaha agar tetap bisa bersaing dengan baik dipasaran. Salah satu strategi tersebut adalah dengan melakukan merger atau menggabungkan dua badan usaha atau lebih. Merger atau penggabungan merupakan perbuatan hukum yang dilakukan oleh satu badan usaha dengan badan usaha lainnya untuk menggabungkan diri dan bersama-sama menjalankan usahanya. Selain merger ada juga bentuk lainnya yang dikenal dengan akuisisi (pengambilalihan), dan konsolidasi (peleburan). Semua bentuk merger dapat dilakukan oleh para pelaku usaha untuk membantu menjalankan usaha mereka. Merger dilaksanakan dengan maksud agar dapat memberikan keefektifan dalam berusaha serta membantu usaha kecil yang sedang membutuhkan dana segar agar usahanya tetap berjalan dengan baik. Untuk menjamin adanya kepastian hukum bagi pelaku usaha yang ingin melaksanakan merger, maka pemerintah membentuk aturan khusus dalam pelaksanaan merger, seperti terdapat dalam UU Antimonopoli.

Di dalam Batang Tubuh UU Antimonopoli terdapat dua pasal yang diamanatkan untuk diatur lebih lanjut dalam Peraturan Pemerintah, yaitu Pasal 28 ayat (3) dan Pasal 29 ayat (2). Pasal 28 ayat (3) berbunyi "Ketentuan lebih lanjut mengenai penggabungan atau peleburan badan usaha yang dilarang sebagaimana dimaksud ayat (1) dan ketentuan mengenai pengambilalihan saham perusahaan sebagaimana dimaksud dalam ayat (2), diatur dalam Peraturan Pemerintah". Sedangkan ketentuan dalam Pasal 29 ayat (2) berbunyi "Ketentuan tentang penetapan nilai aset dan/atau nilai penjualan serta tata cara pemberitahuan sebagaimana dimaksud dalam ayat (1) diatur dalam Peraturan Pemerintah". Pengaturan dalam Batang Tubuh UU Antimonopoli tersebut diatas yang mengamanatkan kepada pemerintah untuk E-ISSN: 2657-0300 Lembaga Penelitian dan Penerbitan Hasil Penelitian Ensiklopedia $\quad 255$ P-ISSN: 2657-0319 
membentuk Peraturan Pemerintah, sehingga terbentuklah PP No. 57 Tahun 2010 tentang Penggabungan atau Peleburan Badan Usaha dan Pengambilalihan Saham Perusahaan yang Dapat Mengakibatkan Terjadinya Praktik Monopoli dan Persaingan Usaha Tidak Sehat (selanjutnya disebut PP No 57 Tahun 2010), yang ditetapkan di Jakarta pada tanggal 20 Juli 2010.

Peraturan Pemerintah tersebut dibentuk guna menciptakan persaingan usaha yang sehat dan wajar dalam hal terjadinya merger, karena merger merupakan salah satu cara bagi pelaku usaha untuk memperoleh keuntungan yang maksimal. Dengan adanya merger, pelaku usaha dapat mengurangi biaya produksi sehingga tercipta produk yang efisien. Selain untuk alasan efisiensi, merger juga merupakan salah satu cara pelaku usaha untuk keluar dari pasar jika pelaku usaha tersebut ingin mendapatkan keuntungan finansial dari perusahaannya atau bagi pelaku usaha kecil jika dianggap tidak ada lagi yang dapat meneruskan usahanya (Syamsul Maarif, 2010). Pelaksanaan merger yang banyak dilakukan oleh pelaku usaha perlu dikendalikan dan diawasi oleh lembaga berwenang yang ditunjuk oleh pemerintah, dalam rangka mengurangi dampak negatif yang ditimbulkan terhadap persaingan. Untuk hal itu, dibentuklah oleh pemerintah sebuah lembaga independen yang bertugas sebagai pengawas tegaknya peraturan dan juga pemberian kepercayaan dari PP merger kepada lembaga tersebut dalam hal terjadinya merger.

Lembaga dimaksud adalah Komisi Pengawas Persaingan Usaha (seklanjutnya disebut KPPU) yang dibentuk untuk mengawasi tegaknya dan dipatuhinya UU Antimonopoli. KPPU adalah sebuah lembaga yang bersifat independen, dimana dalam menangani, memutuskan atau melakukan penyelidikan suatu perkara tidak dapat dipengaruhi oleh pihak manapun, baik pemerintah maupun pihak lain yang memiliki conflict of interest, walaupun dalam pelaksanaan wewenang dan tugasnya bertanggung jawab kepada presiden (Hermansyah, 2008). Dengan tugas dan wewenang yang diemban oleh KPPU, apabila KPPU menemukan dugaan pelanggaran terhadap UU Antimonopoli dan PP merger yang dilakukan oleh perusahaan hasil merger dan memberikan dampak bagi persaingan usaha, maka merger yang telah dilakukan tersebut dapat dibatalkan. Pembentukan PP ini diharapkan dapat mempermudah pekerjaan KPPU dalam hal merger.

Kesepakatan dalam melaksanakan merger ini adalah kesepakatan bagi seluruh anggota dewan direksi, apabila perusahaannya berbentuk persero dan biasanya dilakukan dalam bentuk Rapat Umum Pemegang Saham (RUPS). Bagi perseroan yang terancam pailit, merger dapat menjadi salah satu jalan keluar untuk mengatasi masalah likuidasi bagi kreditor, pemilik dan karyawan. Pelaksanaan merger berpotensi menciptakan dampak negatif terhadap kondisi pasar. Di Amerika Serikat, kekhawatiran utama dari merger yaitu penciptaan atau penguatan kekuatan pasar (market power) dari perusahaan hasil merger. Di Uni Eropa, beberapa dampak yang jadi perhatian sebagai akibat dari suatu merger, yaitu struktur pasar yang berdampak buruk, ketakutan terhadap lahirnya bisnis raksasa, sektor sensitif yang dikuasai asing dan juga pengangguran (Hermansyah, 2008).

Di Indonesia sendiri telah terjadi beberapa kasus merger yang menimbulkan praktik monopoli dan/atau persaingan usaha tidak sehat. Salah satu contohnya yaitu kasus kepemilikan silang Temasek Holdings (Temasek) atas PT Telekomunikasi Seluler (Telkomsel) dan PT Indosat, Tbk., yang dikenal dengan "Kasus Temasek". "Kasus Temasek ini mulai menjadi perkara dan bergulir di KPPU pada April 2007.

256 Lembaga Penelitian dan Penerbitan Hasil Penelitian Ensiklopedia $\quad$ E-ISSN: 2657-0300 
KPPU menilai akibat akuisisi tersebut telah mengurangi tingkat persaingan di pasar dan merugikan konsumen telepon seluler. Diktum No. 4 Putusan KPPU yang dibacakan pada tanggal 19 November 2007 memerintahkan agar Temasek melepaskan kepemilikan sahamnya pada Telkomsel atau PT Indosat, Tbk. Putusan mana yang telah dikuatkan oleh Pengadilan Negeri Jakarta Pusat dan Mahkamah Agung Republik Indonesia. Selain kasus Temasek, KPPU juga telah memeriksa dugaan praktek monopoli yang dilakukan oleh PT Carefour Indonesia (Carefour) pasca akuisisi saham PT Alfa Retailindo, Tbk. (Alfa) dan pada tanggal 3 November 2009 KPPU menyatakan Carefour melanggar UU No. 5 tahun 1999 dalam tindakan akuisisi tersebut dan memerintahkan Carefour untuk melepas kembali kepemilikannya pada Alfa (Hermansyah, 2008).

Merger yang memberikan kerugian bagi masyarakat sebagai konsumen atau bagi pelaku usaha lainnya yang mengurangi persaingan, dilarang menurut UU Antimonopoli, karena bisa menyebabkan timbulnya praktik monopoli dan persaingan usaha tidak sehat. Dampak merger yang menimbulkan kerugian dapat terjadi karena tindakan sendiri yang dilakukan perusahaan hasil merger. Tindakan sendiri terjadi jika hasil merger menciptakan suatu perusahaan dengan kekuatan pasar (market power) yang besar atau secara signifikan meningkatkan kekuatan pasar yang telah dimiliki oleh salah satu perusahaan sebelum merger terjadi (Gunawan Widjaja, 2002). Merger yang memberikan dampak merugikan pada persaingan dan masyarakat dapat terjadi karena tindakan bersama pelaku usaha lain. Tindakan bersama yang dimaksud yaitu tindakan yang dilakukan oleh pelaku usaha yang merupakan pelaku usaha hasil merger, dengan pelaku usaha - pelaku usaha lain dalam pasar bersangkutan (Gunawan Widjaja, 2002). Pelaku usaha dalam bertindak harus memikirkan dengan baik dampak-dampak yang ditimbulkan atas setiap tindakan tersebut, apakah telah sesuai dengan aturan ataukah memberikan dampak buruk bagi masyarakat ataupun bagi pelaku usaha lainnya. Berdasarkan pengalaman, keberhasilan dan ketidakberhasilan perlu dibuat cermin perusahaan yang akan melakukan merger agar kemudian hari perusahaan dapat meningkatkan kinerja ekonominya, sehingga pada gilirannya tidak hanya meningkatkan kesejahteraan konsumen, tetapi juga meningkatkan kesejahteraan nasiona (Supriyadi, 2010)l.

Pelaku usaha dalam melakukan merger harus menyampaikan pemberitahuan kepada pihak KPPU sebagaimana terdapat dalam Pasal 5 PP No. 57 tahun 2010. Pemberitahuan bertujuan untuk mencegah terjadinya praktik monopoli dan persaingan usaha tidak sehat dan pemberitahuan ini bersifat wajib. Melalui pemberitahuan, KPPU dapat menilai dan memberikan pendapat tentang boleh atau tidaknya merger tersebut dilaksanakan. Apabila hasil penilaian KPPU menyatakan bahwa merger yang dilakukan tidak mengakibatkan terjadinya praktik monopoli dan persaingan usaha tidak sehat, maka merger dapat dilanjutkan. Akan tetapi apabila menyebabkan terjadi praktik monopoli dan atau persaingan usaha tidak sehat, maka pelaksanaan merger tersebut harus dibatalkan. Pelaku usaha yang tidak melakukan pemberitahuan kepada KPPU dapat dikenakan denda dan juga pembatalan terhadap merger yang dilakukan karena berisiko mengakibatkan terjadinya praktik monopoli dan persaingan usaha tidak sehat. Untuk hal-hal tersebut diatas keberadaan KPPU sangat diperlukan dalam pelaksanaan merger, selain untuk mengawasi dan menegakkan peraturan perundangundangan yang ada, juga sebagai pihak yang memiliki peran penting dalam melaksanakan merger, khususnya mengenai pelaksanaan pemberitahuan merger serta mengawasi jalannya perusahaan hasil merger. Pengawasan dilakukan guna menghindari terjadinya praktik monopoli dan/atau persaingan usaha tidak sehat. Selain E-ISSN: 2657-0300 Lembaga Penelitian dan Penerbitan Hasil Penelitian Ensiklopedia $\quad 257$ P-ISSN: 2657-0319 
mengawasi, KPPU juga memperhatikan dengan seksama keadaan pasar yang didalamnya terdapat perusahaan hasil merger, sehingga dapat mencegah terjadinya market power, serta persaingan usaha yang sehat tetap berjalan dengan baik dalam pasar.

\section{B. Metodologi Penelitian}

Metode pendekatan yang penulis gunakan adalah metode pendekatan yuridis normatif yaitu pendekatan masalah melalui melalui penelitian hukum dengan melihat norma-norma hukum yang berlaku yang terdapat di dalam peraturan perundangundangan, kontrak atau perjanjian, putusan pengadilan, dan pendapat para ahli. Penelitian ini bersifat deskriptif (Soerjono Soekanto, 2008) yaitu Penulis memberikan gambaran dan analisa mengenai kedudukan KPPU, pelaksanaan dan pengaturan dalam merger, khususnya mengenai Peraturan Pemerintah No. 57 tahun 2010.

\section{Hasil dan Pembahasan}

KPPU merupakan komisi negara independen yang dibentuk UU Antimonopoli dan bebas dari pengaruh serta kontrol pemerintah maupun pihak manapun. KPPU memiliki wewenang menyusun peraturan pelaksanaan, melakukan pemeriksaan terhadap pihak yang diduga melakukan pelanggaran pada UU Antimonopoli, membuat putusan dan mengenakan sanksi hukum yang mengikat terhadap pelaku pelanggaran undang-undang tersebut. Dalam menjalankan tugasnya KPPU memiliki visi dan misi yang menjadi penunjang dalam pelaksanaan wewenang, tugas, dan fungsinya sebagai lembaga yang dibentuk pemerintah.

Visi KPPU sebagai lembaga independen yang mengemban amanat UU Antimonopoli adalah "menjadi lembaga pengawas persaingan usaha yang efektif dan kredibel untuk meningkatkan kesejahteraan rakyat. Sedangkan misi yang dirumuskan KPPU untuk mewujudkan visi dimaksud adalah menegakkan hukum persaingan, menginternalisasikan nilai-nilai persaingan, dan membangun kelembagaan yang efektif dan kredibel. Perumusan visi dan misi ini bertujuan untuk meningkatkan kualitas dan kuantitas KPPU dalam melaksanakan tugas dan wewenang yang diembankan kepadanya sebagai lembaga atau komisi untuk menegakkan persaingan usaha yang sehat. KPPU memiliki kewenangan tersendiri dalam hal persaingan usaha. Dengan kewenangan tersebut KPPU memiliki otoritas penuh terhadap hal-hal yang berkaitan dengan persaingan usaha, baik berupa penegakkan ataupun berupa pelanggaran yang dilakukan oleh pelaku usaha. Kewenangan tersebut cukup luas, mencakup kewenangan legislatif, yudikatif, eksekutif, dan konsultatif. Sedangkan dalam hal pelaksanaan merger, KPPU diberikan kewenangan penuh untuk mengatur pelaksanaan merger terhadap badan usaha yang ada di Indonesia maupun badan usaha asing yang ingin menggabungkan diri dengan badan usaha Indonesia.

Kewenangan yang dimiliki KPPU dalam hal terjadinya merger dapat menjelaskan secara langsung ataupun tidak langsung terhadap kedudukan yang dimiliki KPPU dalam pelaksanaan merger. Kewenangan tersebut dapat berupa pendapat tentang boleh atau tidaknya merger tersebut dilaksanakan dan juga berupa pembatalan pelaksanaan merger pada badan usaha tertentu yang terbukti melakukan pelanggaran dan mengakibatkan terjadinya praktik monopoli dan persaingan usaha tidak sehat. Kewenangan legislatif KPPU terhadap pelaksanaan merger dapat dilihat dalam peraturan-peraturan komisi yang dibentuk oleh KPPU. Dalam hal ini, KPPU 
berhak menciptakan peraturan-peraturannya sendiri sebagai kebebasan yang diberikan pemerintah atas kelembagaannya yang bersifat independen tanpa terpengaruh dari pihak manapun. Seperti dibentuknya Peraturan KPPU Nomor 11 Tahun 2010 Tentang Konsultasi Penggabungan Atau Peleburan Badan Usaha dan Pengambilalihan Saham Perusahaan dan Peraturan KPPU Nomor 13 Tahun 2010 tentang Pedoman Pelaksanaan Penggabungan atau Peleburan Badan Usaha dan Pengambilalihan Saham Perusahaan yang Dapat Mengakibatkan Terjadinya Praktik Monopoli dan Persaingan Usaha Tidak Sehat. Peraturan-peraturan komisi yang dibuat oleh KPPU bertujuan untuk menunjang peraturan perundang-undangan yang ada sehingga dapat memberikan pemahaman yang komprehensif bagi pelaku usaha.

Kewenangan yudikatif KPPU dapat dilihat pada saat adanya pelanggaran yang dilakukan oleh badan usaha hasil merger. kewenangan yudikatif KPPU merupakan kewenangan yang dimiliki KPPU untuk memeriksa perusahaan yang diduga melakukan pelanggaran, kewenangan ini dapat berupa penyidikan dan investigasi lainnya yang penting untuk menemukan bukti terhadap dugaan yang ada. KPPU dapat mengambil tindakan sebagai inisiatif sendiri ataupun dengan adanya laporan dari pihak lain untuk menyelidiki kebenaran dugaan tersebut dengan melakukan pemeriksaan. Setelah KPPU menemukan bukti yang dimaksud dan memang benar telah terjadi pelanggaran, maka KPPU berhak mengadili pelaku usaha sesuai dengan proses yang berlaku untuk diberikan putusan atas pelanggaran yang telah dilakukan.

Kewenangan konsultatif KPPU dalam pelaksanaan merger yaitu diharuskannya para pihak dalam merger untuk melakukan pemberitahuan ataupun secara sukarela melakukan konsultasi kepada KPPU. Pemberitahuan yang dilakukan terlebih dahulu kepada KPPU bertujuan agar dikemudian hari tidak terjadi pelanggaran terhadap peraturan-peraturan yang ada. Sedangkan pelaksanaan konsultasi bertujuan untuk memberikan pertimbangan-pertimbangan yang baik kepada pelaku usaha tentang merger yang akan dilakukan melalui penilaian terhadap rencana merger dan dampaknya bagi perkembangan persaingan untuk masa yang akan datang dengan memberikan pendapat komisi, apakah akan menimbulkan praktik monopoli dan persaingan usaha tidak sehat atau malah sebaliknya, memberikan manfaat yang besar bagi pelaku usaha pada khususnya dan persaingan pada umumnya.

Kedudukan KPPU dalam persaingan usaha adalah lembaga pengawas dan penegak UU No. 5/1999 yang bertugas me-review aspek persaingan atas transaksi merger yang dilakukan (Syamsul maarif, 2008). Setelah diterbitkan Peraturan Pemerintah No. 57 Tahun 2010 tentang Penggabungan atau Peleburan Badan Usaha dan Pengambilalihan Saham Perusahaan yang Dapat Mengakibatkan Terjadinya Praktik Monopoli dan Persaingan Usaha Tidak Sehat (selanjutnya disebut PP No. 57 Tahun 2010), maka KPPU memiliki kedudukan yang lebih jelas dalam hal pelaksanaan merger karena KPPU diberikan kepercayaan sebagai otoritas persaingan untuk melaksanakan PP No. 57 Tahun 2010 tersebut. Maksud otoritas persaingan adalah kepercayaan yang diberikan kepada KPPU untuk melaksanakan dan mengatur jalannya pelaksanaan merger yang ada di Indonesia guna menciptakan persaingan usaha yang baik serta mengawasi jalannya perusahaan hasil merger.

Keberadaan PP No. 57 Tahun 2010 menguntungkan bagi KPPU dan pelaku usaha, karena PP tersebut dapat memberikan kepastian hukum bagi pelaku usaha dan mempertegas kewenangan KPPU dalam hal merger. apalagi setelah terbentuknya PP ini, setiap badan usaha yang melaksanakan merger wajib memberitahukannya kepada KPPU. Sebagaimana, terdapat dalam Pasal 5 ayat (1) PP No. 57 Tahun 2010 yang berbunyi "penggabungan badan usaha, peleburan badan usaha, atau pengambilalihan 
saham perusahaan lain yang berakibat nilai aset dan/atau nilai penjualannya melebihi jumlah tertentu wajib diberitahukan secara tertulis kepada komisi paling lama 30 (tiga puluh) hari kerja sejak tanggal penggabungan badan usaha, peleburan badan usaha, atau pengambilalihan perusahaan".

Apabila dilihat dari perbandingan yang didapat dari data KPPU, sebelum dan sesudah terbentuknya PP No 57/2010 ini, ada perkembangan yang cukup baik dalam hal merger. Sebelum dibentuknya PP No. 57/2010 masih ada perusahaan merger yang tidak melakukan pemberitahuan kepada KPPU terhadap merger yang dilaksanakan, sehingga di kemudian hari terjadi pelanggaran yang mengakibatkan merger yang telah dilakukan, dibatalkan dan memisahkan diri dari kepemilikan terhadap perusahaan yang di-merger. Contohnya dalam kasus Temasek (Temasek Holdings). Dalam kasus ini, temasek melakukan akuisisi terhadap dua perusahaan yang mengakibatkan temasek menjadi pemilik saham silang terhadap PT Telekomunikasi seluler (Telkomsel) dan PT Indosat Tbk.

Kepemilikan saham silang ini dianggap KPPU sebagai praktik monopoli yang mengakibatkan berkurangnya persaingan di pasar khususnya pasar telepon seluler karena akuisisi terhadap dua perusahaan yang bergerak di bidang yang sama yaitu telepon seluler. Dengan diakuisisinya kedua perusahaan tersebut, maka temasek menjadi pusat kekuatan ekonomi pasar yang pada akhirnya dapat menentukan keadaan pasar dalam persaingan pasar raksasa yang dimilikinya terhadap telepon seluler tersebut. Kasus ini terjadi karena tidak adanya kekuasaan penuh yang dimiliki oleh KPPU untuk menegaskan kepada para pihak dalam merger agar melakukan pemberitahuan untuk mencegah secara dini kemungkinan munculnya praktik monopoli dan persaingan usaha tidak sehat.

Secara teori dapat dinyatakan, bahwa sebelum terbentuknya PP merger, KPPU tidak dapat bertindak tegas terhadap badan usaha yang tidak melakukan pemberitahuan karena peraturan yang ada hanya berasal dari inisiatif KPPU untuk menciptakan peraturan dimaksud sehingga sifatnya tidak mengikat tetapi hanya bersifat mengatur. Akan tetapi, setelah dibentuknya PP No. 57 Tahun 2010 KPPU memiliki otoritas yang lebih banyak dan lebih pasti karena telah diberikan kepercayaan oleh PP No. 57 Tahun 2010 untuk menerima pemberitahuan merger yang bersifat wajib dilakukan oleh pelaku usaha serta aturannya bersifat mengikat dan memaksa. Pembentukan PP No. 57 Tahun 2010 semakin memberikan titik terang terhadap kedudukan KPPU dalam pelaksanaan merger. KPPU akan memberikan penilaian terhadap pemberitahuan merger yang dilakukan badan usaha, mengenai boleh atau tidak bolehnya merger tersebut dilaksanakan.

Merger merupakan perbuatan hukum yang dilakukan oleh pelaku usaha untuk menggabungkan dua atau lebih usaha, demi menciptakan keefektifan dan memberikan keuntungan bagi masyarakat dan pelaku usaha itu sendiri. Merger dilakukan atas kesepakatan yang diperoleh masing-masing pelaku usaha. Biasanya merger dilakukan oleh badan usaha yang berbentuk perseroan terbatas (selanjutnya disebut PT). Bagi badan usaha yang berbentuk PT, undang-undang yang mengaturnya adalah UndangUndang No. 1 Tahun 1995 tentang Perseroan Terbatas yang diganti dengan UndangUndang No. 40 Tahun 2007 tentang Perseroan Terbatas. Penggantian undang-undang ini karena ketentuan dalam UU No 1 Tahun 1995 dirasa tidak lagi memadai dan memenuhi perkembangan hukum dan kebutuhan masyarakat, maka pemerintah 
mengganti UU No. 1 Tahun 1995 dengan UU No. 40 tahun 2007 (selanjutnya disebut UUPT).

Menurut Pasal 1 angka 1 UUPT yang dimaksud dengan perseroan terbatas adalah badan hukum yang merupakan persekutuan modal, didirikan berdasarkan perjanjian, melakukan kegiatan usaha dengan modal dasar yang seluruhnya terbagi dalam saham dan memenuhi persyaratan yang ditetapkan dalam undang-undang ini serta peraturan pelaksanaannya. Dalam UUPT terdapat ketentuan mengenai penggabungan, peleburan, dan pengambilalihan yang diatur dalam BAB VII mengenai Penggabungan, Peleburan, Pengambilalihan dan Pemisahan yang memuat 15 pasal, yaitu Pasal 122 s/d Pasal 137. Berdasarkan UUPT ini, pemerintah membentuk aturan khusus yang dijadikan pedoman dalam melaksanakan merger bagi perseroan terbatas yaitu PP No. 27 Tahun 1998 tentang Penggabungan, Peleburan, dan Pengambilalihan Perseroan Terbatas.

Apabila dilihat lebih dalam antara hubungan UUPT dengan UU Antimonopoli, maka dapat diberikan pertimbangan bahwa persaingan usaha terjadi karena banyaknya badan usaha yang saling bersaing memberikan hasil produksi yang berkualitas kepada konsumen. Sedangkan untuk mengatur agar badan usaha tersebut tidak keluar dari jalur peraturan perundang-undangan, maka dibentuklah UUPT. Begitu juga dengan persaingan yang terjadi, perlu pengaturan yang tepat agar tidak memberikan kerugian kepada pelaku usaha sebagai produsen dan juga masyarakat sebagai konsumen. Dengan demikian, antara UUPT dengan UU Antimonopoli tidak dapat dipisahkan karena adanya saling ketergantungan antara keduanya. Apabila salah satu dihilangkan, maka dapat mengakibatkan kerugian yang harus ditanggung oleh pelaku usaha ataupun oleh masyarakat sebagai konsumen.

Pembentukan UU Antimonopoli tidak terlepas dari adanya pengaturan terhadap badan usaha khususnya mengenai UUPT, karena pada awal kemerdekaan RI, Indonesia tidak memiliki peraturan yang memadai mengenai badan usaha maupun mengenai antimonopoli bahkan pada zaman orde baru terjadi monopoli persaingan oleh satu badan usaha. Badan usaha tersebut menjadi penguasa dalam pasar, sehingga munculnya monopoli dan persaingan usaha tidak sehat. Dengan monopoli yang terjadi memberikan kerugian pada pelaku usaha yang lain, karena tidak mampu menyaingi perusahaan yang memiliki monopoli dimaksud. Pasca runtuhnya orde baru, pemerintah berinisiatif membentuk peraturan khusus yang mengatur tentang Antimonopoli dan persaingan, sehingga badan usaha yang ada dapat bersaing secara wajar dan bagi yang melanggar ketentuan tersebut dikenakan sanksi. Dengan dibentuknya UU Antimonopoli, maka UUPT yang telah lebih dulu dibuat, dapat bekerja sama mengatur jalannya persaingan antar badan usaha yang terjadi di pasaran. Pelaksanaan merger yang terjadi dalam PT, harus mematuhi dan mengikuti segala ketentuan yang terdapat dalam UUPT ataupun PP No. 27/1998 untuk selanjutnya mengikuti aturan dan ketentuan yang terkandung dalam UU Antimonopoli maupun dalam PP No. 57 Tahun 2010. Dalam melakukan proses merger ada tahapan yang harus dipenuhi oleh badan usaha dan selanjutnya diserahkan kepada KPPU untuk melakukan pemberitahuan, yaitu tahapan yang dilakukan oleh badan usaha dalam pelaksanaan merger dan tahapan merger menurut PP No. 57 Tahun 2010.

\section{Penutup}

Kedudukan KPPU dalam hal terjadinya merger yaitu KPPU berhak untuk membatalkan atau melanjutkan merger yang dilakukan oleh pelaku usaha. Selama merger yang dilaksanakan tidak menimbulkan praktik monopoli dan atau persaingan usaha tidak sehat, maka merger dapat dilaksanakan. Pelaku usaha wajib mematuhi dan E-ISSN: 2657-0300 Lembaga Penelitian dan Penerbitan Hasil Penelitian Ensiklopedia $\quad 261$ P-ISSN: 2657-0319 
mengikuti setiap aturan dan ketentuan yang diberikan oleh KPPU dalam melakukan penggabungan demi menciptakan persaingan yang sehat dan bebas dari praktik monopoli. Pelaksanaan merger dilakukan dalam dua tahapan, yaitu tahap persiapan dan tahap pelaksanaan. Dalam tahap persiapan, merger dipersiapkan dalam internal perusahaan masing-masing badan usaha merger untuk mencari kesepakatan. Dibuat rancangan penggabungan untuk dimintakan persetujuan dalam Rapat Umum Pemegang Saham yang biasa disebut RUPS. Dengan persetujuan RUPS, dilakukan pengumuman dalam 2 (dua) surat kabar dan pengumuman tertulis kepada karyawan perusahaan tentang rencana merger. Kemudian diajukan surat permohonan kepada menteri dengan melampirkan akta perubahan Anggaran Dasar dan akta Rancangan Penggabungan untuk mendapat persetujuan Menteri. Perusahaan hasil merger dapat didaftarkan dalam daftar perusahaan dan diumumkan dalam Tambahan Berita Negara Republik Indonesia. Tahap kedua, memenuhi ketentuan dalam PP No. 57 Tahun 2010 yaitu melakukan pemberitahuan secara tertulis kepada KPPU tentang rencana merger dalam jangka waktu 30 (tiga puluh) hari kerja setelah tanggal merger berlaku efektif yuridis. Kemudian KPPU memberikan Penilaian tentang boleh atau tidaknya merger dilaksanakan. Selain pemberitahuan, pelaku usaha dapat melakukan konsultasi secara sukarela baik disampaikan tertulis maupun dengan lisan yang pada akhirnya juga dilakukan penilaian atas konsultasi tersebut.

\section{Daftar Pustaka}

Fuady. Munir, Hukum Tentang Merger, Bandung:PT Citra Aditya Bakti, 2008

Ginting. Jamin, Hukum Perseroan Terbatas (UU No. 40 Tahun 2007), Bandung:PT Citra Aditya Bakti, 2007

Hermansyah. Pokok-Pokok Hukum Persaingan Usaha di Indonesia, Jakarta:Kencana, 2008.

Lay. Alexander, dkk. Efektifitas Regulasi Merger dan Akuisisi Dalam Kerangka Hukum Persaingan Usaha, Jakarta:Pustaka Sinar Harapan, 2010.

Maarif. Syamsul. Merger dalam Perspektif Hukum Persaingan Usaha, Jakarta:Degraf Publishing, 2010.

Moin. Abdul, Merger, Akuisisi, dan Divestasi, Yogyakarta:Ekonisia, 2010

Nadapdap, Binoto, Hukum Acara Persaingan Usaha, Jakarta:Jala Permata Aksara, 2009.

Rokan. Mustafa Kemal, Hukum Persaingan Usaha (Teori dan Prakteknya di Indonesia), Jakarta:Rajawali Pers, 2010.

Simanjuntak. Cornelius dan Natalie Mulia, Merger Perusahaan Publik, Suatu Kajian Hukum Korporasi, Bandung:PT Citra Aditya Bakti, 2006

Siswanto. Arie, Hukum Persaingan Usaha, Jakarta:Ghalia Indonesia, 2002.

Soekanto. Soerjono. Pengantar Penelitian Hukum, Jakarta:UI-Press, 1986.

Sunggono. Bambang. Metodologi Penelitian Hukum, Jakarta:Rajawali Pers, 2010.

Usman. Rachmadi, Hukum Persaingan Usaha di Indonesia, Jakarta:PT Gramedia Pustaka Utama, 2004.

Widjaja. Gunawan, Merger dalam Perspektif Monopoli, Jakarta:PT RajaGrafindo Persada, 2002. 